\title{
Succession in family farming: gender and future perspectives
}

\author{
Sucessão na agricultura familiar: gênero e perspectivas de futuro \\ Sucesión en agricultura familiar: género y perspectivas futuras
}

Received: 03/05/2021 | Reviewed: 03/11/2021 |Accept: 03/13/2021 | Published: 03/20/2021

\author{
Juçara Elza Hennerich \\ ORCID: https://orcid.org/0000-0002-0237-4095 \\ State University of Western Paraná, Brazil \\ E-mail: jucaraeh@gmail.com \\ Clério Plein \\ ORCID: https://orcid.org/0000-0002-7235-9771 \\ State University of Western Paraná, Brazil \\ E-mail: clerioplein@gmail.com \\ Luciana Oliveira Fariña \\ ORCID: https://orcid.org/0000-0002-5466-4887 \\ State University of Western Paraná, Brazil \\ luciana.farina@unioeste.br \\ Márcia Hazen \\ ORCID: https://orcid.org/0000-0002-4882-7010 \\ State University of Western Paraná, Brazil \\ Email: marciahanzen@hotmail.com \\ Flávia Piccinin Paz Gubert \\ ORCID: https://orcid.org/0000-0002-8179-8426 \\ State University of Western Paraná, Brazil \\ Email: flavia@gubertepaz.com
}

\begin{abstract}
The succession processes in rural properties, in particular, in family farming, has taken priority status among the themes that involve the rural environment. The present study was carried out in the extreme west of the state of Santa Catarina, between the years 2016 and 2017, when 268 farmers were interviewed. In addition to the objective of recording and discussing data related to succession, gender and generational processes, the research was also carried out as a didactic tool for agricultural sciences courses in the region. The study recorded the desire, regardless of gender, of $5.5 \%$ of young people to break connection with agriculture in their future and not participate in the succession processes. Result that opposes the point of view of the parents, who express a gender distinction in the succession role, where $72.4 \%$ relates the male gender to such, while for the female gender the desire of $94 \%$ of fathers and mothers is that the daughters, respectively, get married and / or live in the city. The study points out the importance of actions involving the parents of rural youth in succession and gender issues that are increasingly urgent in the possible future of family farming.
\end{abstract}

Keywords: Rural youth; Family succession; Rural women; Rural sociology.

\section{Resumo}

Os processos sucessórios nas propriedades rurais, em particular, na agricultura familiar, tem tomado status de prioridade entre as temáticas que envolvem o meio rural. O presente estudo foi desenvolvido na região extremo oeste do estado de Santa Catarina, entre os anos de 2016 e 2017, quando foram entrevistados 268 agricultores. Além do objetivo de registrar e discutir os dados referentes aos processos sucessórios, de gênero e geracionais, a pesquisa foi realizada também como uma ferramenta didática de cursos de ciências agrárias da região. O estudo registrou o desejo, independente de gênero, de 5,5\% dos jovens em romper os laços com a agricultura em seu futuro e não participar dos processos de sucessão. Resultado que contrapõem o ponto de vista dos pais e mães, que expressam uma distinção de gênero no papel sucessório, onde 72,4\% relaciona o gênero masculino para tal, enquanto que para o gênero feminino o desejo de $94 \%$ dos pais e mães é de que as filhas, respectivamente se casem e/ou morem na cidade. O estudo aponta a importância de ações, que envolvam os pais e mães dos jovens rurais nos assuntos sucessórios e de gênero que cada vez mais urgentes no futuro possível para a agricultura familiar.

Palavras chave: Juventude rural; Sucessão familiar; Mulheres rurais; Sociologia rural.

\section{Resumen}

Los procesos de sucesión en las propiedades rurales, en particular, en la agricultura familiar, han tomado un lugar prioritario entre los temas que involucran al medio rural. El presente estudio se realizó en el extremo occidental del estado de Santa Catarina, entre los años 2016 y 2017, cuando se entrevistaron a 268 agricultores. Además del objetivo 
de registrar y discutir datos referentes a sucesión, género y procesos generacionales, la investigación también se llevó a cabo como herramienta didáctica para los cursos de ciencias agrícolas en la región. El estudio registró el deseo, independientemente del género, del 5,5\% de los jóvenes de romper vínculos con la agricultura en su futuro y no participar en los procesos de sucesión. Resultado que se opone al punto de vista de los padres y madres, quienes expresan una distinción de género en el rol sucesorio, donde el 72,4\% relaciona el género masculino con el mismo, mientras que para el género femenino el deseo del $94 \%$ de los padres y madres es que las hijas, respectivamente, se casan y / o viven en la ciudad. El estudio destaca la importancia de acciones que involucren a los padres y madres de la juventud rural en materias de sucesión y género que son cada vez más urgentes en el posible futuro de la agricultura familiar.

Palabras clave: Juventud rural; Sucesión familiar; Mujeres rurales; Sociología rural.

\section{Introduction}

The discussion involving the theme of family succession permeates other themes such as the delrease of the rural population, and was already on the Europe agenda in the 1960s. In Brazil, however, the subject took on "concern" status in the 1980s, although demographic data show that between 1960 and 1980, 27 million farmers migrated to urban life (Camarano \& Abramovay, 1998).

Abramovay and Camarraro (1998), estimated that in the previous 50 years, one in three Brazilians would leave the countryside to build their life in the urban environment. Similar figures were published by the Ministry of Agrarian Development (MDA) (2008), showing that between the 1950s and 2006 the rural population decrease more than 47\%, it is important to note that more than 50\% of the total was concentrated between 1980 and 2000 (Ministério do Desenvolvimento Agrário, 2008).

Corroborating these data between 2006 and 2017, according to Brazilian Institute of Geography and Statistics (IBGE), data, there was a $9.5 \%$ reduction in the number of family farming business, also dropping in the overall percentage of rural business from $83.2 \%$ to $76.8 \%$ in the respective years, and in 2017 they occupied $23 \%$ of the area destined to agriculture in Brazil. Another reduction registered was in the number of employed persons in this category of establishments, which in 2006, including members of the management families, were 12.282 million people, this number decreased to 10.116 million, a decrease of $17.6 \%$. Within this scenario, the reduction in the number of individuals in the families, whether due to the birth rate or the exodus of young people, is one of the causes pointed out by the IBGE itself. Data from the 2017 census also point to the economic importance of family farming, in the state of Santa Catarina for example, is responsible for $50.6 \%$ of the value generated by agricultural production.

Within this scenario, the topic has aroused the interest of researchers, mainly for issues related to masculinization and rural aging. Several works address these issues to the economic difficulties and the degree of accessibility to the professional training of these young people, who in this context choose to leave the rural environment.

Ribemboim and Moreira (2007), classify as driving forces of migration, those of "expulsionist" origin or "attractiveness" origin. Still according to the same authors in the case of rural-city migration, these forces could be both of the "deterministic rural expulsionism" type - when the rural man has no alternative but to migrate -, and of the "possibilist urban attractiveness" type - in this case, by rational choice, in search of better wages and income throughout its life cycle.

These two forces continue to act on the processes of rural - urban migration, but these are more concentrated among rural youth. According to Froehlich et al. (2011), public policies such as rural retirement increased the possibility of elderly people remaining in rural areas. However, for a good part of the young population, who grew up in the midst of the difficulties found for the socioeconomic reproduction of the productive units and with greater access to schooling with an urban bias, the city is still seen as a promising future.

According to Ferrari (2004), the devaluation of life in the countryside denotes the greater interest in staying in the city for these young people from rural families, for them the city is the promise of a better future, where they find opportunities for 
work and fun. It is important to note that these reasons are often reinforced by the parents, who, due to the hard work in rural areas, encourage their children to seek other ways.

The consequence of this scenario is the arrival, in the cities, of a large number of young people with insufficient preparation to compete in the urban labor market, reflected in the aging of family farmers, and the lack of prospects for successors to work in the city. land generates what can be called bottlenecks of family farming, with true "rural asylums" (Ferrari, 2004).

Over the past 10 years, numerous public policies aimed at improving life in the countryside, whether from an economic point of view as a cultural partner, have been implemented with apparent success, but they do not seem to be enough to reverse the migration decision of these young people and are in apparent forgetfulness in the last 3 years, with big reductions in budget, management and applicability, culminating in a "low incidence together and diminished articulation between public policies for family farming" (Sousa, et al. 2019, p.4).

When Froehlich et al. (2011), cites the professional qualification with urban bias, understanding in relation to migration is facilitated, however when this qualification is turned to the rural bias the understanding of the factors involved still differs from the theories discussed in current studies.

In another aspect, the succession and migratory processes can be related to gender issues, studies show that young and single rural women are much more likely to leave the countryside and seek different positions in the urban market. In this sense, Faria et al. (2019), when focusing on migration allied to gender issues in a study in the North of Minas Gerais, highlights that the female presence in mobility processes is related to the historical roots of the peasantry, reproduced in the domestic environment, giving the mother the construction of the role of daughters in domestic reproductive activities. In addition, factors such as the submission of women to family relationships, attributed to patriarchal inheritance, the gender emphasis linked to domestic work, the indivisibility of domestic work, the exclusion or distancing from commercial agricultural activities, in which they act as a complementary force and sometimes invisible, are also important elements in the decisions taken by rural youth (Brumer, 2007).

The above considerations outlined the present study, which is outlined in the considerations of rural families on the succession and future processes of family farming properties in the western region of Santa Catarina. The study aims to confront the opinions, desires and choices of fathers, mothers, sons and daughters about their future in family farming and rural property.

\section{Methodology}

The study was carried out in the extreme west and west regions of Santa Catarina, respectively in the municipalities of São José do Cedro, Maravilha, and Quilombo. The research was carried out along with agronomy courses at UNOESC University of the West of Santa Catarina from July to December 2016, at the São José do Cedro and Maravilha campuses and at UFFS - Federal University of Fronteira Sul, Chapecó campus at the time from February to July 2017. In addition to the objective of recording and discussing data referring to succession, gender and generational processes, the research was also carried out as a didactic tool for the information and awareness of the students involved.

The research is descriptive. The method is qualitative, quantitative, where the results are analyzed together in both perspectives (Pereira, et al. 2018), since the study works with a particular reality, composed of social and cultural specificities, better expressed with the combination of the two methods (Minayo, 1996). It is worth mentioning Yin (2015) who considers that qualitative and quantitative methods are not excluded and can be important in complementing each other and allowing a better understanding of the phenomena under study. The methodological procedure is descriptive, based on data and facts gathered from the researched reality (Bervian \& Cervo, 2002). 
To outline the study proposed here, semi-structured questionnaires were prepared, which addressed: the characterization of the property, the family structure, the succession in the properties, the economic and productive structure, and mainly the intentions related to the future of the establishments regarding the continuity of activities productive and social structure. 268 farmers of different age groups were interviewed, detailed in Table 1.

Table 1 - Details of data collection.

\begin{tabular}{|c|c|c|c|c|c|}
\hline \multirow[t]{2}{*}{ Municipality } & \multicolumn{2}{|c|}{$\begin{array}{l}\text { Number of managers (fathers / } \\
\text { mothers) interviewed. }\end{array}$} & \multicolumn{2}{|c|}{$\begin{array}{c}\text { Number of young people between } \\
15 \text { and } 29 \text { years of age. }\end{array}$} & \multirow[t]{2}{*}{$\begin{array}{l}\text { Total of interviews } \\
\text { conducted. }\end{array}$} \\
\hline & Female & Male & Female & Male & \\
\hline São José dos Cedros & 37 & 38 & 12 & 9 & 96 \\
\hline Maravilha & 34 & 37 & 9 & 11 & 91 \\
\hline Quilombo & 31 & 34 & 7 & 9 & 81 \\
\hline Total & 102 & 109 & 28 & 29 & 268 \\
\hline
\end{tabular}

Legend: The table describes the municipalities, genders, age groups and structural functions within the families surveyed, as well as the quantification of the categories described. Source: Hennerich et al. (2021).

After data collection, these were grouped by theme and analyzed by family and municipality. The quantitative and qualitative analysis follows the precepts of basic descriptive statistics, followed by tests of proportion and averages, considering the intercessions and proportions of the groups analyzed.

The interviews were conducted in a separate space for fathers / mothers and sons and daughters. The questions developed were the only choice among the proposed alternatives. The age range of the participants analyzed, and presented here, is for fathers and mothers over 35 and sons and daughters between 10 and 29 years of age.

\section{Results and Discussion}

The data expressed in Figure 1 show the desire of the interviewed farmers' sons and daughters when asked about their future.

Figure 1 - Children's desire for their own future.

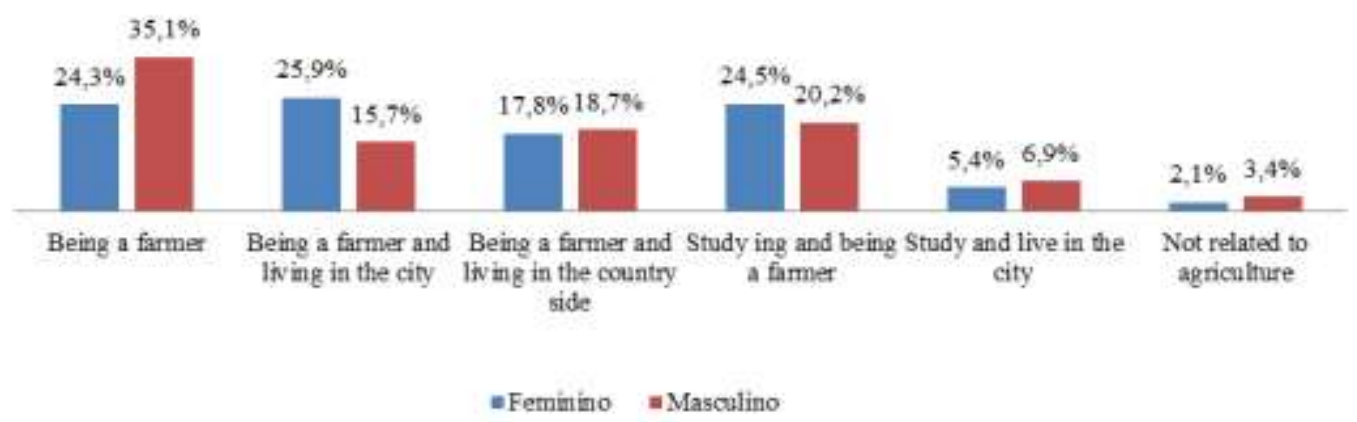

Caption: The graph presents the alternatives offered as an answer for the sons and daughters of farmers to the question: what do you want for your future. Source: Hennerich et al. (2021).

In Figure 1, it is possible to observe that the desire to be a farmer, as a single element, is present in more than $35 \%$ of the male respondents and more than $24 \%$ of the female gender. When the option is to be a farmer and live in the city, women are the highest percentage in relation to men. The option of being a farmer and living in the countryside remains in a percentage between 17 and $19 \%$ with less than $1 \%$ difference between the genders analyzed. The first analyzes can point out 
some important reflections, which for a greater perspective will be added here to the facts of reduction in the number of children per family and the aging of the managers of the rural properties.

Paulilo (2000, p.2), already highlighted in the decade of 90 to 2000, the reduction of the number of individuals in rural families, from a global perspective, and present in a gradual scale in Brazil, more emphatically in the South region. According to the author, Brazil is "among the countries that showed a drop of more than $40 \%$ in the fertility rate" among women in general "in a period of 20 years". Castiglioni (2020, p.12), reinforces the statement, noting that "the total fertility rate, of 6.16 children per woman in 1940, began to decline during the 1960s, dropping to 1.77 in 2018", the author also points out, the almost equalization of this rate between rural and urban areas.

The reality is a population emptying of the rural environment, considering that until the mid-sixties, family farming establishments were characterized by families with a "high number of children", which forced these families to "often adopt procedures that reduce the number of potential heirs, such as sending children for military or religious careers, as well as via study funding" (Anjos, et al. 2006, p.12).

This reality, however, is more complex than the suggested reduction of individuals approach, involves the attractions of the rural environment as opposed to urban centers, issues related to income, the hardship of working on rural property, access to information and leisure, the difficulties of dialogue with managers directly linked to management autonomy, gender issues and the masculinization of rural areas (Carneiro, 1999; Mello et al. 2003; Spanevello, 2008), among other factors, that they present to families and society in general, the reality of aging and the reduction of the productive potential of food, especially with regard to species diversity.

In view of the above arguments, we look at the results shown in Figure 1, where 5.5\% of the young people interviewed say they do not want to have any future relationship with agriculture. Among the others, this relationship appears as intended, being combined with different housing situations and access to the study.

The data also shows the desire of women in relation to the study, mainly as an option for use in property management, in their succession as farmers. According to IBGE (2017), rural women, from family farming, are still the minority with access to studies, the data show that among the inhabitants of rural establishments with completed high school, up to 35 years of age, $20 \%$ are from female and more than $79 \%$ are male, reflecting the lack of gender equity in rural society, the result of gender definitions within the family itself, reproduced for generations, regardless of gender or social institution, to a greater or lesser degree, also printed in the succession processes (Figure 2).

Access to studies is a relevant factor in young people's considerations about whether or not to stay on the property, since training offers the opportunity for contact and mastery of information and knowledge, however, it also promotes a comparison between rural and urban life (Brumer, Spanevello, 2008) since educational institutions are usually in urban areas.

Complementarily to this aspect, the present study registered a curious and needless approach in new studies, where 98\% of the interviewees (in all age groups) recognize themselves happy in the countryside, and when asked about seeing this happiness in the inhabitants of the urban environment, 78\% affirm that they believe that they are not happy, the interviewees listed the issues of health, stress and poor diet as a possible justification for this condition of urban life in their views. The transversal question, presented in the debates, when presenting the study in rural communities, proposed to the parents the following reflection: what do I want for the future of my sons and daughters, since I foresee a future of unhappiness in the urban environment? Although this issue is fraught with subjectivity, and needs clarification and further elaboration, it was observed that it is capable of creating an opportunity for debate within the participating families and relating aspects of advantages and disadvantages between going or staying, both for fathers and mothers, as well as for sons and daughters.

Matte \& Machado (2016, p.135) state that: 
Regardless of the factors capable of motivating young people to leave the countryside, the fact is that today the new generations are focused on reproducing individual projects and not necessarily family collectives. In this sense, the parents' decision for the successor is directly related to the child's own will to stay and take over the property.

Considering that the present study shows a percentage of the majority of young people interviewed who wish to succeed their parents on the property, other components must be analyzed, including the incentive given by parents for effective succession. In this sense, many farmers understand their life in agriculture as a bad alternative for their children's future, due in large part to the "demotivation of parents" that "is related to productive difficulties such as climate change and the change in prices and costs of markets" (Matte; Machado, 2017, p.144), to which is added Silva's report (2011, p.3) that the image of rural youth is seen as negative in the face of contemporary society. For the author, "the characterization of the young person from the countryside is already imbued with a load of prejudiced meanings that treat this category as subjects that do not deserve due trust". For the understanding in the present study, this confidence refers to the intellectual and financial capacity to recognize the success patterns dictated by urban society, often different from those in rural areas. This indicates yet another need for future studies to analyze these disparities in patterns. and relate them to the apparent (in the view of farmers) urban unhappiness.

For Brumer and Anjos (2008, p.12) the succession implies a process of internalizing the activity and the possibility of its option during the creation and education of the children:

This succession implies a previous socialization in the activity, which started during childhood, and which, to a large extent, occurs "in practice". This means that [...] it is difficult for someone to become a family farmer based on exclusively school learning. In this sense, agricultural technical courses, such as "alternation schools" or "rural family houses", recruit their students mainly among the children of farmers, qualifying the knowledge of young people previously socialized in the activity [...], the beginning of professional learning in agriculture rarely occurs in the adult phase of individuals.

The authors' statement places the definition of this possibility in the hands of parents and dependents of their own contentment and appreciation in agricultural activity. Mello et al. (2003), claim, however, that this is a historically constructed role for men. For the authors, the succession process in family farming is dependent on the articulations around the father figure, who besides determining the occasion and the form to transfer of the family patrimony, is responsible for identifying among the children the most propitious to follow in the field and then starts to prepare it according to the perspective proposed by Brumer and Anjos (2008).

When the approach is carried out with a focus on gender issues, Faria et al. (2019, p.105) point to a basic reflection, for the understanding of these relationships in rural areas. According to the authors, "Generally, being a" rural youth and woman "translates into a position of" inferiority "within the social hierarchy, contributing to the social invisibility of young people in rural areas". One of the most concrete data of this scenario is that among the 3.897,408 business classified as family farming, only $20.07 \%$ are managed by women, on this data, it is important, however, to note that among non-family farming business this percentage is even lower, $17.06 \%$.

These factors contribute to the decision to leave the field among young women. According to Brumer (2007) women are more likely to migrate to the urban environment, due to different factors, all from a certain angle linked to the patriarchal construction of social definitions, among which, due to the condition of submission of women in relationships within the family, low, or not even a value, either of recognition or monetary given to the work performed by them in the productive units and within the maintenance and care of the family, environments where in general it is seen as an accessory, seen as helper, confined to actions and reproductive relations, while men are responsible for the actions and relations of production and protagonism. 
Figure 2 - Fathers and mothers' desire for their children's future.

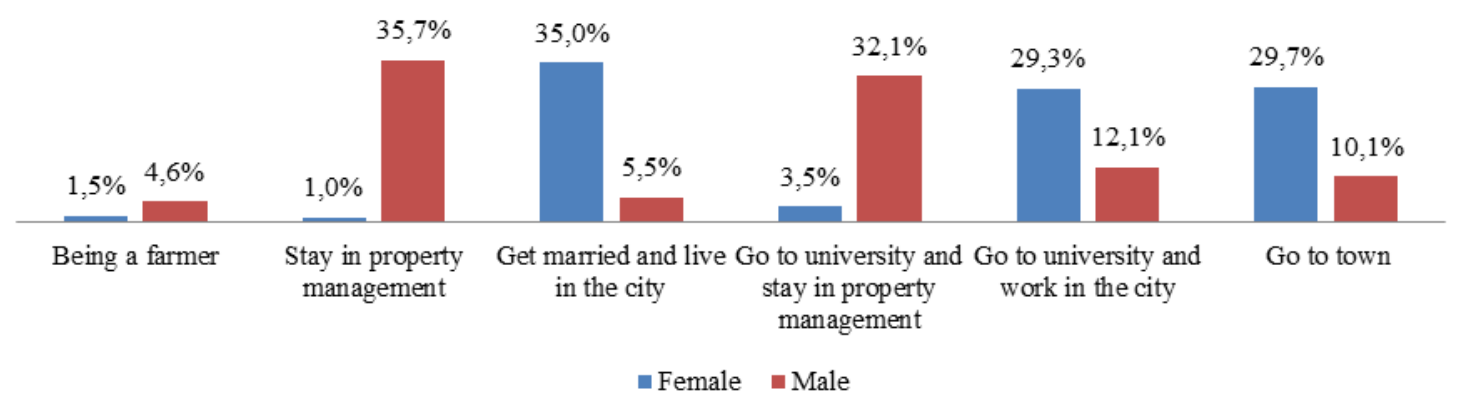

Caption: The graph presents the alternatives offered as an answer for the fathers and mothers of rural youth to the question: what do you want for the future of your son and / or daughter. Source: Hennerich et al. (2021).

Figure 2 adds elements to this discussion and illustrates as a "background" the way these patriarchal definitions are reproduced from the family environment in the units studied.

The data shown in Figure 2 expresses the conflicting opinion of parents in relation to the future of their children in comparison with their wishes. It is possible to observe that for $72.4 \%$ of the interviewees the option is in the succession carried out by the male gender, so that they simply remain in the property management or else they attend the university and stay in the property management. When viewed from the perspective of the future for daughters, $94 \%$ of respondents respectively want their daughters to get married and live in the city, attend university and live in the city or simply go to the city.

For Herrera (2013) the role of women in rural areas is generally underestimated by society, not even recognized as a job category, but as an aid to the main job of the male individual. This can be listed as one of the factors that possibly guide the opinions expressed by fathers and mothers, whether these are motivated at the very center of the exposed patriarchal concept or in the search to reduce the pain to be faced in the face by imposed definitions and reproduced.

In return for the analysis of Figure 1, it is possible to verify that $92.5 \%$ of the young women interviewed expressed the desire to be farmers and participate in the succession in rural properties, in contrast to the opinion of fathers and mothers. The fact denotes in a first glance the lack of dialogue or perception between fathers, mothers and daughters and in a second a verification of the structural machismo and its tendency to reproduction in family farming.

It is necessary to break with the invisibility of the work of rural women, since they act beyond the domestic environment, also in the production, management, conservation of the production unit, where, as main activities, the production of food for family consumption or commercialization, the treatment and handling of animals, mainly small livestock, both for consumption and for the sale of surpluses, and also practices oriented to the commercialization of agricultural products (Herrera, 2013), at fairs, directly for urban and also rural consumers, agroindustrialization activities, in addition to the fundamental role in the education of children and consequently in the reproduction of family farming as a productive and social structure.

These patriarchal and sexist definitions, established culminate in the highest percentage of women who migrate to urban centers in search of better living conditions and even personal and financial independence.

[..] in the countryside, women have less opportunity for economic autonomy, as well as decision-making. This ends up being a major factor in the exodus of young women, which is also the result of patriarchal relations and the search for greater freedom and autonomy. In the recent period, the higher schooling of young women pushes them to the city, in some cases, with their incorporation in precarious and poorly paid jobs, but which can enable the continuity of studies. (Silva, 2011, p. 5). 
The departure of young women from the countryside is still involved in a range of factors, in access to land, normally seen as the natural inheritance of male children, in difficult access to the financial means of maintaining their individualities and even to the productive unit, also linked to perspectives of the future and also, in the visualization of the reproduction of the role of the mother, who usually points out the future of this young woman to marry, and continue in functional invisibility. Second, Câmara, et al. (2020, p.11), this reality "stems from the patriarchal construction in which the man is seen as a representative of the interests of the house, with decision-making power and the woman helps him, and carries out the reproductive work".

Directly one of the consequences of this scenario is the masculinization of the countryside and the increase in migration to the urban, without dating or marriage options, the male children also begin to migrate to the city, or to structure a life of work in the countryside and housing in the city. (Faria et al. 2019). In both perspectives, challenges are imposed on the managers of the units and society itself, among which is aging without children at home, without daughters-in-law and grandchildren (a common structure until the mid-1980s, 1990s), the finding of workforce and financial results reducing the need for health care, until many choose to sell their properties and move to the cities with their children, or continue in rural areas with reduced areas and no production and maintenance power, having retirement and other social benefits as its financial structure.

The table below shows the reduction in the quality of life of elderly rural managers, whether due to low financial movements, health consequences, normal age and a life of heavy work, permeated by the difficulty of access to public health services and for the apparent loneliness. In another invitation to subjective reflection, the word "loneliness" was expressed by $74.8 \%$ of the fathers and mothers interviewed as being their greatest fear in the future.

The fact is that the transformations in the rural environment, especially those involving family farming, are taking place in an intense and continuous way, and involve social structures and definitions, technical and structural elements of the productive unit itself, availability, methodology and intellectual training of the company. technical assistance and rural extension, awareness and performance of universities, colleges, schools, on succession themes and development alternatives for family farming, which, above all, involve the dialogue between country and children.

It is important to rescue, in this reflection, the study by Abramovay et al. (1998, p.16), and refer again to society the question asked in the scope of that study "Who will be responsible for the management of agriculture and the rural environment from now on?" to which is added "Who will produce food for future generations?". The words written by the authors, at the time, still seem to have no responses to effective public, social, economic and environmental policies that can meet the proposed alert: "Letting the family production units themselves answer this question is missing the opportunity to use socially vocations and capacities [...] The rural exodus is urgent ", in this way, the alert is reaffirmed and complemented: actions to help discuss the succession and gender processes in family farming are urgent.

In this sense, one of the lines of work to be considered in future studies and actions is the need to work with fathers and mothers on the themes of succession and gender. The family needs to be aware of the new ways of the rural, be they for society, for the economy or for the environment, all transversely seen in a mixture of possible genres, generations and realities. Among the realities it is important to consider those referring to regionalities, the diversity of territorial, social, economic, cultural and environmental realities, which must be observed both in the diagnosis of situations and in the search for alternatives.

Emphasizing the search for dialogue, one of the possible alternatives is to focus on actions that are based on the concepts of communion, whether carried out in the family unit, in the rural community or in society, considering that in all these instances transformations, adaptations, and, above all, respect for individual and collective rights and freedoms.

The proposed reflection adds to the words of Santos (2017, p.44-45): 
It cannot be said that the rural youth of today has similarities with the rural youth of ten years ago. The involvement with globalization and modern technology has transformed societies. However, being an active member of a society that transforms, modernizes and presents new ways of understanding space is not enough perception to say that the worker and / or farmer is no longer a worker and / or farmer, that the rural youth is more urban than in the field. If urban characteristics are to mix with rural ones, or vice versa, it is a factor dependent on the individual himself and not a classification that must be imposed. The right to belong, recognition and actions that involve human identity must be respected by society.

Among the descriptive responses of the study, it was possible to verify the wishes of both young people and their parents, which, systematized, point out directions and actions for a possible succession process. Among them, young people affirm that fathers and mothers need to understand that the rural youth has new alternatives for forms of production, ideas, proposals, they need, according to them, to listen, analyze, discuss, encourage, participate, understand (words registered in responses), that these proposals or ideas may be more connected with technologies that are not in the domain of the unit manager, that may also be more connected with urban reality, involving institutions, relationships different from those experienced until then, again being willing to learn , understand, evaluate together with family members and again participate in the construction processes. In the statements of fathers and mothers, the words are repeated, understand, discuss, analyze. In addition to the request for young people to hear more, there is the desire that they respect the stories and customs built, value their knowledge and understand what they can teach not only about productive processes, but about being a farmer, about the relationship with the land, with the family and with the community (excerpts taken from the statements of fathers and mothers).

In a certain angle, the results presented here contradict or complement, punctually the statement by Oliveira et al. (2021, p.2), who considers that although efforts have been made in the recognition of family farming and in the construction of public policies in order to curb the rural exodus was lacking, advances in the considerations and transformations underway, "such as demographic issues that involve the reduction of fertility rates and succession in rural areas, impacted by the young people's lack of interest in remaining in the countryside", to which the study developed here, adds the lack of interest, action or perception of fathers and mothers in the permanence of these young people in the field.

The discussion on the need and effectiveness of this succession process is based on the youth's experience and education, both within the family unit and by the social institutions that surround family farming.

Brizzolla et al. (2020, p. 4), reinforces by stating that "the child's participation, together with his parents in the management of rural work, will enable him to develop skills and interest in taking over the business in the future".

Emphasis that is also given to the structural need of society and the country in relation to the continuity and resistance of family farming, considering the maintenance of food sovereignty and the economic potential of the territories, reaffirming the need and urgency in the construction of efficient public policies that assist the succession processes in all its aspects.

\section{Conclusion}

The study records the desire of the majority of young people interviewed to continue in rural areas, in different arrangements that need to be better understood, studied and considered. This desire is common between the male and female genders. This point of the study proposes a new look at the permanence of young women in the field, by choice and not by fatality.

From the point of view of the interviewed fathers and mothers, there is a gender distinction in the succession role, considering male children in their succession desires, even in the different arrangements proposed by the study. The vision is, above all, a continuous challenge to understand and consider new patterns of succession and at the same time to break patterns based on patriarchy, in a necessary and possible construction of gender equity. 
The reflections proposed here point to new fields of studies, analyzes, research and actions, related to working with fathers and mothers on matters of succession and gender, which seem urgent in the compression and delineation between the wishes of fathers, mothers, children and daughters and in the very possible future for family farming.

It is necessary to consider that in addition to specific actions, these constructions require a framework of support and reflexes, which are dependent on public policies, governmental, institutional actions, access to land, credit, technology, training, but also awareness raising. society in general, valuing the family farmer, proposing actions of conscious consumption that can place the food and its producer in the centrality that is natural and necessary.

\section{References}

Abramovay, R. \& Camarano, A. A. (1998). Êxodo rural, envelhecimento e masculinização no Brasil: panorama dos últimos cinquenta anos. Revista Brasileira de Estudos da População, 15 (2), 45-66.

Abramovay, R (1998). Agricultura familiar e serviço público: novos desafios para a extensão rural. Cadernos de Ciência \& Tecnologia, 15 (1), $132-152$.

Anjos, F. S. Dos, Caldas, N. V. C. \& Caetano, M. R. (2006). Pluriatividade e sucessão hereditária na agricultura familiar. Anais do XLIV Congresso da Sober: “Questões Agrárias, Educação no Campo e Desenvolvimento”. Fortaleza: Ceará. 1-21. https://ageconsearch.umn.edu/record/145057/

Bervian, P. A., \& Cervo, A. L. (2002). Metodologia científica (5th ed.): Prentice Hall.

Brizzolla, M. M. B., Chapoval, A. N., Krawszuk, G. L. \& Berlezi, M. (2020). Sucessão familiar em propriedades rurais. Research, Society and Development, 9(10), 1-26. http://dx.doi.org/10.33448/rsd-v9i10.9408

Brumer, A. (2007). A problemática dos jovens rurais na pós-modernidade. In: Carneiro, M. J. \& Castro, E. G. de. Juventude Rural em Perspectiva, 35-52.

Brumer, A. \& Spanevello, R. M (2008). Jovens agricultores da Região Sul do Brasil. (Relatório de Pesquisa). UFRGS; Chapecó: Fetraf-Sul/CUT.

Brumer, A. \& Dos Anjos, G. (2008). Gênero e reprodução social na agricultura familiar. Revista Nera, 11(12), 6-17.

Câmara, A. A. F., Soares, P. B. D. S. \& Zavatário, L. C. (2020) Agroecologia e emancipação de gênero: Protagonismo das mulheres do as sentamento Osvaldo de Oliveira. Research, Society and Development, 9(9), 1-29. http://dx.doi.org/10.33448/rsd-v9i9.8104

Camarano, A. A. \& Abramovay, R (1999). Êxodo rural, envelhecimento e masculinização no Brasil: panorama dos últimos 50 anos. Texto para discussão $N^{o}$ 621. IPEA. 1-23.

Carneiro, M. J. (1998). O ideal urbano: campo e cidade no imaginário dos jovens rurais. In: Teixeira da Silva, F. C., Santos, R., \& Costa, L. F. C. Mundo Rural e Política. Rio de Janeiro, Campus/Pronex.

Castiglioni, A. H. (2020). Transição urbana e demográfica no Brasil: características, percursos e tendências. Ateliê Geográfico, 14(1), 6-26. https://doi.org/10.5216/ag.v14i1.5946

Costa, M. C., Marques, M. J. \& Soares, J. S. F. (2015). Violencia contra mujeres rurales: género y acciones de salud. Escola Anna Nery, 19(1), $162-168$.

Fagotti, L. N. (2017). Associativismo e agricultura familiar: reflexões sobre uma associação de produtores rurais no interior paulista. REDD: Revista Espaço de Diálogo e Desconexão, 9(1)(2). Araraquara, São Paulo, Brasil. https://doi.org/10.32760/1984-1736/REDD/2017.v9i1.10948

De Freitas, C. C. (2007). Associação de mulheres: a resistência feminina nos assentamentos rurais. Revista em Extensão, 6 (1), 40-50. http://www.seer.ufu.br/index.php/revextensao/article/view/20346/10825

Faria, A. J. G., Ferreira, M. L. \& Paula, A. M. N. R. (2019). Exôdo rural feminino, gênero e ruralidades: consequências da migração da juventude rural feminina do distrito de Muquém - Mirabela/MG. Revista Grifos, (47), 98-119.

Ferrari, D. L. (2003). Agricultura familiar, trabalho e desenvolvimento no Oeste de Santa Catarina (Dissertação de mestrado). Universidade Estadual de Campinas, Instituto de Economia, Campinas, São Paulo, Brasil. http://repositorio.unicamp.br/bitstream/REPOSIP/286191/1/Ferrari_DilvanLuiz_M.pdf

Ferrari, D. L., Abramovay, R., Silvestro, M. L., Mello, A. M. \& Testa, M. V. (2004). Dilemas e estratégias dos jovens rurais: ficar ou partir? Estudos Sociedade e Agricultura, 12 (2), 237-271.

Froehlich, J., Rauber, C., Carpes, R. \& Toebe, M. (2011). Selective exodus, masculinization and rural aging in the central Region of the RS. Ciência Rural, 41(9), 1674-1680. https://www.scielo.br/scielo.php?pid=S0103-84782011005000124\&script=sci_abstract

Herrera, K. M (2013). Uma análise do trabalho da mulher rural através da perspectiva da multifuncionalidade agrícola. Anais do Seminário Internacional Fazendo Gênero, Florianópolis, Santa Catarina, Brasil. $\quad$ http://www.fg2013.wwc2017.eventos.dype.com.b r/resources/anais/20/1373328660_ARQUIVO_ArtigoFazendogenerofinal.pdf

Instituto Brasileiro de Geografia e Estatística (2017). Censo Agropecuário 2017. https://sidra.ibge.gov.br/pesquisa/censo-agropecuario/censo-agropecuario2017

Instituto Brasileiro de Geografia e Estatística (2010). Censo Demográfico 2010. https://biblioteca.ibge.gov.br/visualizacao/periodic os/94/cd_2010_religiao_deficiencia.pdf 
Machado, A. G. \& Caume, D. J (2008). Novas funções e novas atividades como alternativas de desenvolvimento da agricultura familiar no Brasil. Raízes, 27(1), 97-104.

Mello, M. A., Abramovay, R., Silvestro, M. L., Dorigon, C., Ferrari, D. L. \& Testa, V. M. (2003). Sucessão hereditária e reprodução social da agricultura familiar. Agricultura, 50 (1), 11-24. http://www.iea.sp.gov.br/out/publicacoes/asp-1-03-2r.htm

Matte, A., Machado, J. A. D. (2017). Tomada de decisão e a sucessão na agricultura familiar no sul do Brasil. Revista De Estudos Sociais, 18(37), 130-151. https://doi.org/10.19093/res.v18i37.3981

Minayo, M. C. S. O Desafio do Conhecimento: pesquisa qualitativa em saúde. Hucitec/Abrasco.

Ministério do Desenvolvimento Agrário (2010). Plano nacional de desenvolvimento rural sustentável. Brasília, DF. http://sit.mda.gov.br/download/ptdrs/ptdrs_qua_territorio063.pdf

Oliveira, M. F., Mendes, L. \& Vasconcelos, A. C. V. H. (2021). Desafios à permanência do jovem no meio rural: um estudo de casos em Piracicaba-SP e Uberlândia - MG. Revista de Economia e Sociologia Rural, 59(2), 1-19. https://doi.org/10.1590/1806-9479.2021.222727

Paulilo, M. I. S. (2000). Movimento de mulheres agricultoras: terra e matrimônio. Cadernos de Pesquisa. Florianópolis: UFSC, 21 , 1-17.

Pereira, A. S., Shitsuka, D. M., Parreira, F. J. \& Shitsuka, R. (2018) Metodologia da pesquisa científica. UFSM, NTE, 1-119.

Ribemboim, J. \& Moreira, F. G. L. (2007). Rural-urban migration in Northeastern Brasil: 'rural deterministic expulsion' or 'urban possibilistic attractiveness'? Anais do LASA's XXVII International Congress, Montreal.

Santos, A. S. (2017). Um olhar sobre as juventudes rurais: desafios, possibilidades e limitações no município de Porteirinha - MG (Dissertação de Mestrado). Programa de Pós-Graduação em Sociedade, Ambiente e Território, Universidade Federal de Minas Gerais, Universidade Estadual de Montes Claros. https://repositorio.ufmg.br/bitstream/1843/NCAP-ASBEKR/1/arthur_saldanha_disserta_o_2_atualizada_saldanha_a..pdf

Silva, E. J. (2011). Do campo para a cidade: as relações de gênero e o êxodo das jovens mulheres. Anais do Seminário nacional gênero e práticas culturais olhares diversos sobre a diferença. UFPB: João Pessoa, Pernambuco, Brasil.

Sousa, N. D., Sousa, C. S. M. \& Rodrigues, W. (2020). Análise das políticas públicas para a agricultura familiar: o que tem feito o governo do Tocantins? Revista Desafio, 7(4), 1-15. doi https://doi.org/10.20873/uftesp2020-8764

Spanevello, R. M. (2008) A situação das filhas na transmissão do patrimônio na agricultura familiar. Anais Fazendo Gênero 8 - Corpo, Violência e Poder. Florianópolis, santa Catarina, Brasil. https://docplayer.com.br/42599648-A-situacao-das-filhas-na-transmissao-do-patrimonio-na-agricultura-familiar.html

Spanevello, R. M (2008). A dinâmica sucessória na agricultura familiar (Tese de Doutorado). Programa de Pós-Graduação em Desenvolvimento Rural, Universidade Federal do Rio Grande do Sul, Porto Alegre, Rio Grade do Sul, Brasil. http://www.lume.ufrgs.br/handle/10183/16024.

Yin, R. K. O Estudo de caso. Bookman. 